\title{
The birth of endocrine pathology
}

\author{
How Erdheim misunderstood parathyroids
}

\author{
Anton H. M. Vermeulen
}

Received: 25 May 2010 /Revised: 9 July 2010 / Accepted: 18 July 2010 /Published online: 3 August 2010

(C) The Author(s) 2010. This article is published with open access at Springerlink.com

The structure that would later be called the parathyroid gland was first observed around 1850, the second half of the nineteenth century in which so many new discoveries in anatomy and histology were made [1]. The first description of "a small compact yellow glandular body" [3] was followed 30 years later by the notion that removal of this structure might be responsible for acute tetany occurring after thyroidectomy. This was the period during which detailed anatomical and histological observations led to increased understanding of bodily functions in health and disease, including that of the parathyroids [2]. The pathologist Jacob Erdheim (1874-1937) built on these new discoveries in elucidating through clinical observations as well as experimental studies how parathyroids play a role in calcium metabolism and how their dysfunction leads to serious bone pathology. The story illustrates that scientific discovery is not a linear process: Erdheims understanding of parathyroid function was hampered through his misinterpretation of some of his observations.

\section{The first observation and discovery of the parathyroid glands}

The first written observation of a parathyroid gland was made by Richard Owen (1804-1892) in an Indian Rhinoceros with a weight of approximately 5,000 lbs avoirdupois $( \pm 2,267 \mathrm{~kg})$. Owen described "a small compact yellow glandular body was attached to the thyroid at the point

A. H. M. Vermeulen $(\bowtie)$

Department of Pathology, Maastricht University Medical Center,

P. Debyelaan 25,

6229 HX Maastricht, The Netherlands

e-mail: ahmverm@gmail.com where the veins emerge" [3]. The dissection took place during the winter months of 1849-1850, and Owen presented his findings at a meeting of the Zoological Society on February the 12th, 1850. The lecture was published in 1862 in the "Transactions of the Zoological Society" [4].

The definitive discovery of the parathyroid glands was made in 1877 by Ivar Sandström (1852-1889, Fig. 1) then a medical student. As a prosector at the department of anatomy in Uppsala he published his findings in the "Upsala Läkareförenings Förhandlingar for 1879-1880", (Fig. 2) a Swedish journal [5, 6]. Sandstrom wrote: "About three years ago (1877) I found on the thyroid gland of a dog a small organ, hardly as big as a hemp seed, which was enclosed in the same connective tissue capsule as the thyroid, but could be distinguished therefrom by a lighter color. A superficial examination revealed an organ of a totally different structure from that of the thyroid, and with a very rich vascularity ...." [6]. Hampered by lack of time and shortage of material Sandström could only continue his studies in the winter of 1880 after a delay of 2 years. While his investigations embraced several species, including man, dog, cat, rabbit, ox, and horse, his main interest was the anatomy and the microscopic features of these glands in humans. In 43 completely performed autopsies Sandström was able to demonstrate two parathyroid glands on each side of the thyroid; in seven cases of in situ dissections he found a smaller number of these tiny glands. Sandström gave a meticulous description of these glands, concerning their anatomic localization, size, shape, and color. In his microscopic examination he described the parathyroids as "vascular glands", richly vascular structures made up of solid fields, trabeculae, and glandular cells, sometimes arranged in follicles with focal presence of colloid, but without ducts (Fig. 3). 


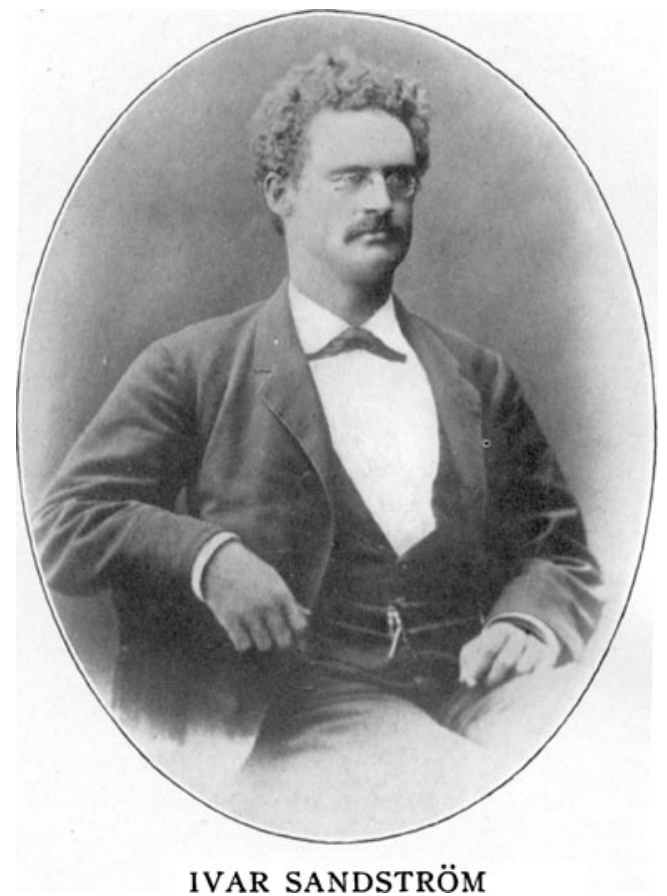

Fig. 1 Ivar Sandström (1852-1889) [6]

Referring to the embryological studies of the thyroid by Robert Remak [7] two decades earlier, and the contemporary studies of Kölliker [8], Sandström considered his "structures" to be embryonic thyroid glands arrested in

\section{UPSALA LÄKAREFÖRENINGS FÖRHANDLINGAR}

$1879-1880$.

N:r $7 \& 8$

\section{Fredagen den 5 Mars.}

SANdström, Glandulæ parathyreoideæ. - Blix, Myograf. SAndSTröm, Prostatapreparat. - Wide, Lefverpreparat. - HolmGren, Retinaströmmen. - Svar till $H$. Cohn om färgblindheten. Föreningens yttrande mot $K$. Wickseils föredrag om dryckenskap.

\section{Om en ny körtel hos menniskan och átskilliga däggdjur}

\section{af}

Ivar Sandström.

För snart tre år sedan påträffade jag å sköldkörteln af en hund en liten, knappt hampfröstor bildning, som låg innesluten

Fig. 2 Announcement of Sandström's discovery of the parathyroid glands [5]. Courtesy of the library University of Amsterdam (UvA, UBM: V.V. 1241) various stages of development and named them "glandulae parathyreoideae". Sandström had no notion of the physiological significance of the parathyroids, but he assigned them an important role in the pathological growth process particularly given their embryonic nature. With due respect he pointed to previous descriptions of these glands by Remak, who described them in kittens [7] and by Virchow in man [9]. His excellent presentation of the subject was translated into German and sent to a German Journal. Remarkably, the article was refused because of excessive length, a reason open to serious debate given the enormous size of many scientific articles in German Journals those days! As an abstract the paper was finally published in 1880 in a few German Journals [10].

\section{The rise of thyroid surgery and its complications}

\section{Cachexia strumipriva and tetany}

Sandström's discovery remained unnoticed for more than 10 years, coincidentally a period when thyroid surgery not only achieved its first successes but also experienced significant and severe complications, particularly in some parts of Switzerland, those days known for many cases of endemic goiter [11]. Theodor Kocher (1841-1917) from Bern, considered by many as the father of thyroid surgery, popularized the idea that removal of the thyroid gland did not induce adverse effects in man. Jacques-Louis Reverdin (1842-1929) from Geneva held similar views. Kocher, however, was alerted by disturbing information reported by Reverdin, who described a number of strumectomized patients who showed alarming symptoms of increasing anemia, physical and mental inertia. Kocher succeeded tracing 34 patients, 20 of them showed various stages of myxedema and cretinism. Shortly afterwards in 1883 during a spring meeting for German surgeons in Berlin, Kocher warned his colleagues to abandon total strumectomy [12]. The same year Kocher published his article on the effects of total strumectomy and introduced the term "Cachexia strumipriva" (myxedema after total thyroidectomy) [13].

In addition to these long-term complications, surgeons were becoming increasingly alarmed by one of the acute complications after (sub-)total strumectomy, namely the unpredictable occurrence of tetany that could result in a fatal outcome. In 1881, Nathan Weiss (1851-1883) published a thorough clinical and neurophysiological study on tetany in which he presented three of Billroth's patients who suffered from postoperative attacks of tetany [14]. In one case the attack proved fatal. Weiss believed that there was a causal link between the occurrence of tetany and surgery, hereby departing from the traditional view that tetany and cachexia strumipriva were simply successive 
Fig. 3 a Transection through the parathyroid and part of the thyroid gland in dog. Acid potassium bichromate $2 \%$ solution, eugenol, Canada Balsam. Vessels injected. Drawn at Hartnack object 4 , ocular 3 , tube not drawn out; $\mathbf{b}$ section of the parathyroid from man. Blood vessels injected. Acid potassium bichromate $2 \%$ solution, carmine, eugenol, Canada Balsam. Drawn at Hartnack object 4, ocular 3, tube not drawn out [6]

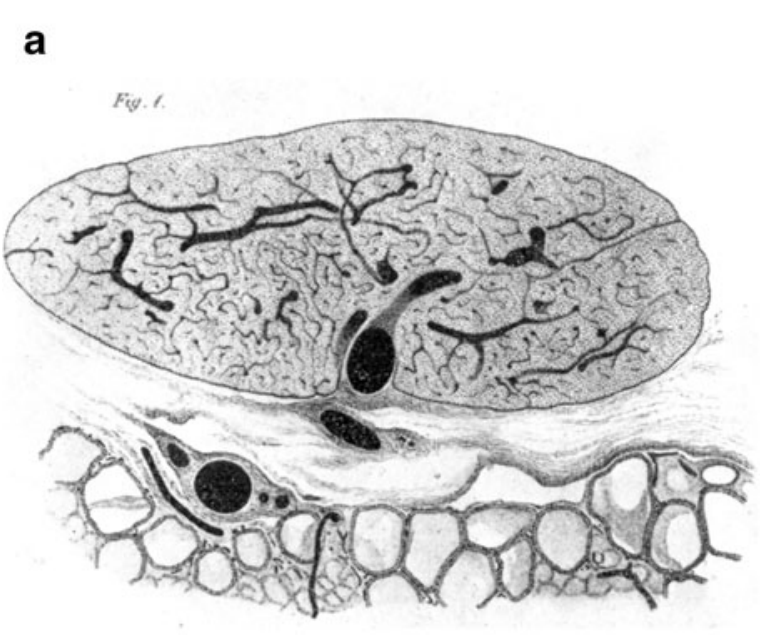

stages of a single disorder caused by strumectomy [15]. By animal studies Gley made an attempt to unravel the causes of these two complications and was the first investigator to draw attention to Sandström's parathyroid glands.

\section{The first animal experiments}

Eugéne Gley (1857-1930), professor of physiology at the School of Medicine in Paris, provides a stellar example in history of pathology and medicine, not only of the use of planned animal experiments for the investigation of clinical problems, but also the importance of a thorough study of the literature as an intrinsic part of the experimental design. In the 1880 edition of Schmidt's Jahrbücher [16], Gley became acquainted with Sandström's abstract, describing the parathyroids. The "Jahrbücher" was notable for publishing lectures and investigations from every discipline in medicine inside and outside Germany in a concise but comprehensive survey [17]. So, after a lapse of more than 10 years, Gley rediscovered the external parathyroid glands and named them "glandules thyroidiennes" $[18,19]$ because he, like Sandström, regarded the parathyroids as embryonic thyroid tissue. In his animal experiments Gley showed that simultaneous removal of the thyroid and two external glandules thyroidiennes (as he named "thyreoidectomie complète") led to a lethal tetany in $90 \%$ of his cases. Notably, removal of both external parathyroids leaving the thyroid gland unaffected did not provoke any symptom of tetany. Unfamiliar with the actual total number of parathyroids in rabbits, coupled with incomplete microscopic observations, Gley drew the erroneous conclusion that: " $a$ true functional association may possibly exist between the thyroid and the parathyroid glands" and was unable more clearly to define their function [20]. Nonetheless, Gley was the first investigator to assign a vital role of the parathyroid glands, albeit that the role still lacked clear definition.

\section{Alfred Kohn, Giulio Vassale, and Francesco Generali}

Alfred Kohn (1867-1959) dedicated his whole life to the study of endocrine organs, utilizing the rich resources of the department of histology of Prague that provided a reliable anatomical basis for his experimental investigations. By means of preparing numerous serial sections through the thyroid gland and adjacent organs of the neck in humans and several mammals, Kohn demonstrated the presence of four parathyroids in cat [21] and rabbit [22]: two external parathyroids and two parathyroids within the thyroid gland, one within each lobe; these 'internal' parathyroids were unknown to Gley providing the source of some confusion in his experiments in rabbits. Unlike both Sandström and Gley, Kohn was convinced of the separate identity of the parathyroid glands. Because Kohn questioned from the beginning the identical nature of thyroid and parathyroid glands he gave the latter the non-committal term "Epithelkörperchen" (epithelial bodies), taken from Maurer's article about amphibians [cited in 21], a nomenclature still common in recent German literature. Applying Kohn's results, the Italian investigators, Giulio Vassale (18621912), a pathologist from Modena and Francesco Generali, demonstrated in their first animal experiments that removal of all parathyroid glands in cat and dog, leaving the thyroid gland intact, ended in fatal tetany in both species [23]. From these experiments the investigators concluded that the parathyroids play a unique and separate role and should not be considered as embryonic thyroid remnants. Further they were unable to show any compensatory function of the parathyroid glands after removal of the thyroid. In a second set of experiments Vassale and Generali carried out a series of parathyroidectomies, ranging from removal of only one to a total removal of the parathyroids, with and without thyroidectomy. Once again they came to the same conclusion; the parathyroids were separate organs, distinct from the thyroid. [24]. 


\section{Osteitis fibrosa in "Virchow's Festschrift"}

Virchow's (1821-1902) 70th birthday in 1891 was a notable occasion that merited special celebration. To mark the event 13, of his residents, men like Friedrich Daniel von Recklinghausen (1833-1910, Fig. 4), Edwin Klebs (1834-1913), and Paul Grawitz (1850-1932), compiled and published a festschrift entitled: "Festschrift Rudolf Virchow zu seinem 71. Geburtstage" [25]. The festschrift (Fig. 5), illustrated with (chromo-) lithographic figures and tables contained contributions on pathology, physiology, and chemistry was a remarkable testament of the times in pathology. It included an extensive 89-page contribution by Von Recklinghausen entitled: "Die fibröse oder deformirende Ostitis, die Osteomalacie und die osteoplastische Carcinose in ihren gegenseitigen Beziehungen (.....in their mutual relations)" [26], in which he presented 16 cases of various bone disorders, categorized into three groups as indicated in the title. Under the heading of 'fibrous osteitis', Von Recklinghausen described a number of cases of Paget's disease and two cases of osteitis fibrosa-like bone disorders. Fifty years later these latter two cases were revisited and revised by the endocrinologist Fuller Albright (1900-1969) as polyostotic fibrous dysplasia [1]. Besides four patients with osteoplastic bone metastases Von Recklinghausen also discussed (under the heading: "extensive bone malacia") five (!) subcategories of osteomalacia, and one condition, being his immortal case of osteitis fibrosa.

This famous case starts with the touching clinical history of Herr Bleich, translated by Albright: "Herr Bleich was a 40 year old married mason who years before had undergone a mercury cure for syphilis. In April 1888, he fell from a 3-m high ladder onto his left side; eight days later he was admitted to the Surgical Clinic because of severe pain in his hip joint. It was not clear whether a fracture of the neck of the femur or a coxitis was present. He was treated with extension until August, when improvement was so far advanced that he began to walk with a stick. In October the patient slipped, fell against a bench, and fractured his clavicle. He was readmitted to the Surgical Clinic. There he underwent a transverse fracture of the diaphysis of

Fig. 4 Von Recklinghausen as Professor of Pathology at the University of Strassbourg in the period 1872-1906. Courtesy of Verlag Degener \& Co, Inh Manfred Dreiss [38]

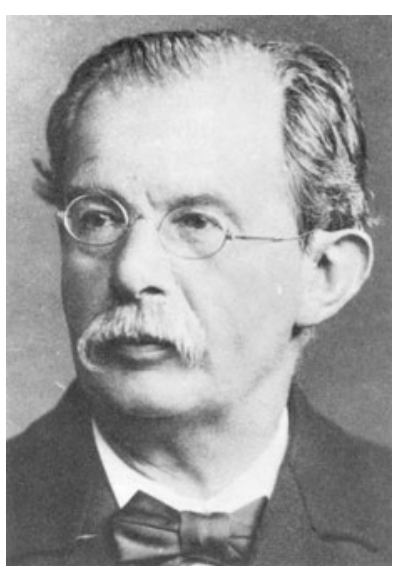

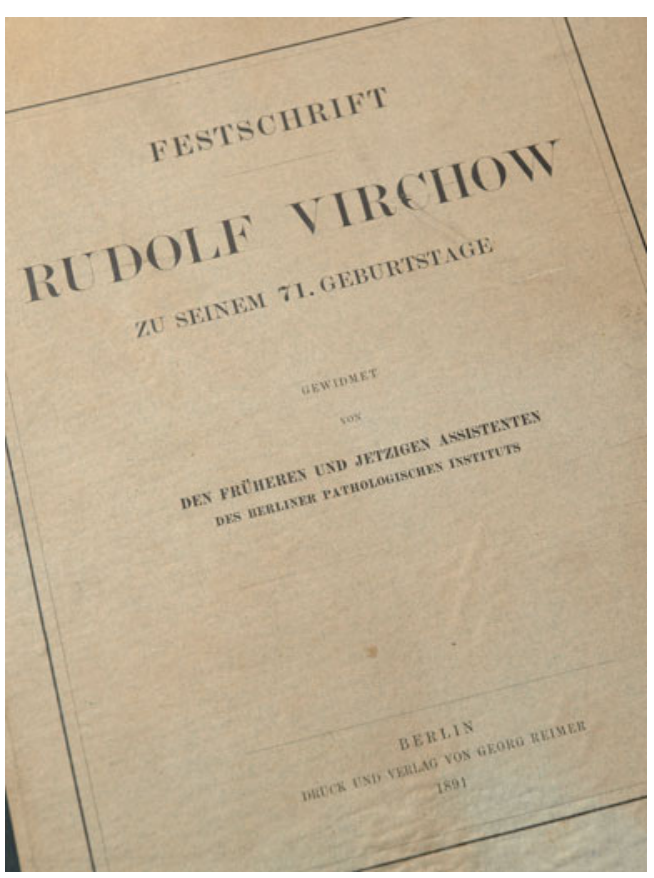

Fig. 5 Festschrift dedicated to Rudolf Virchow's 71st birthday by his former and present residents. The book was printed and published in 1891, the year Virchow celebrated his 70th (!) birthday (October 13, 1891) [25]

the right femur while lying in bed, the bedpan was clumsily maneuvered! Continued pain and unsatisfactory union made it necessary to transfer him to a nonclinical division of the City Hospital. When he was again examined in the Clinic in the course of the summer of 1889 , he not only showed the most extensive bending of several long bones, but complained of excruciating pain in many bones and appeared very emaciated. Although the fracture seemed to heal, the patient was unable to raise the leg; marasmus increased and he died on October 4, 1889" [1]. Urine was never tested [26].

The clinical picture is followed by a detailed anatomical and microscopic examination of the skeleton revealing all the characteristics of severe hyperparathyroidism: many skeletal deformities, fractures, fibrosis, hematogenous pigment, cysts (Fig. 6), and conglomerates of giant cells. This case reported by Von Recklinghausen and diagnosed as "Fibröse Ostitis. Multiple Osteosarkome", was classified as " metaplastic malacia", in which metaplasia indicates replacement of preexisting compact bone by newly formed fibrous osteoid. By use of the designation "Osteosarkome", Von Recklinghausen referred to the brown tumors termed "Myeloidtumoren" or "Riesenzellensarkomen", a nomenclature that still was employed in 1910 in his posthumously published monograph "Untersuchungen über Rachitis und Osteomalacia" [27].

On the basis of his microscopic findings von Recklinghausen concluded that the cause of many forms of chronic fibrotic osteitis, including the Bleich case, was to be found in pathologic changes within the vascular system. In his mono- 


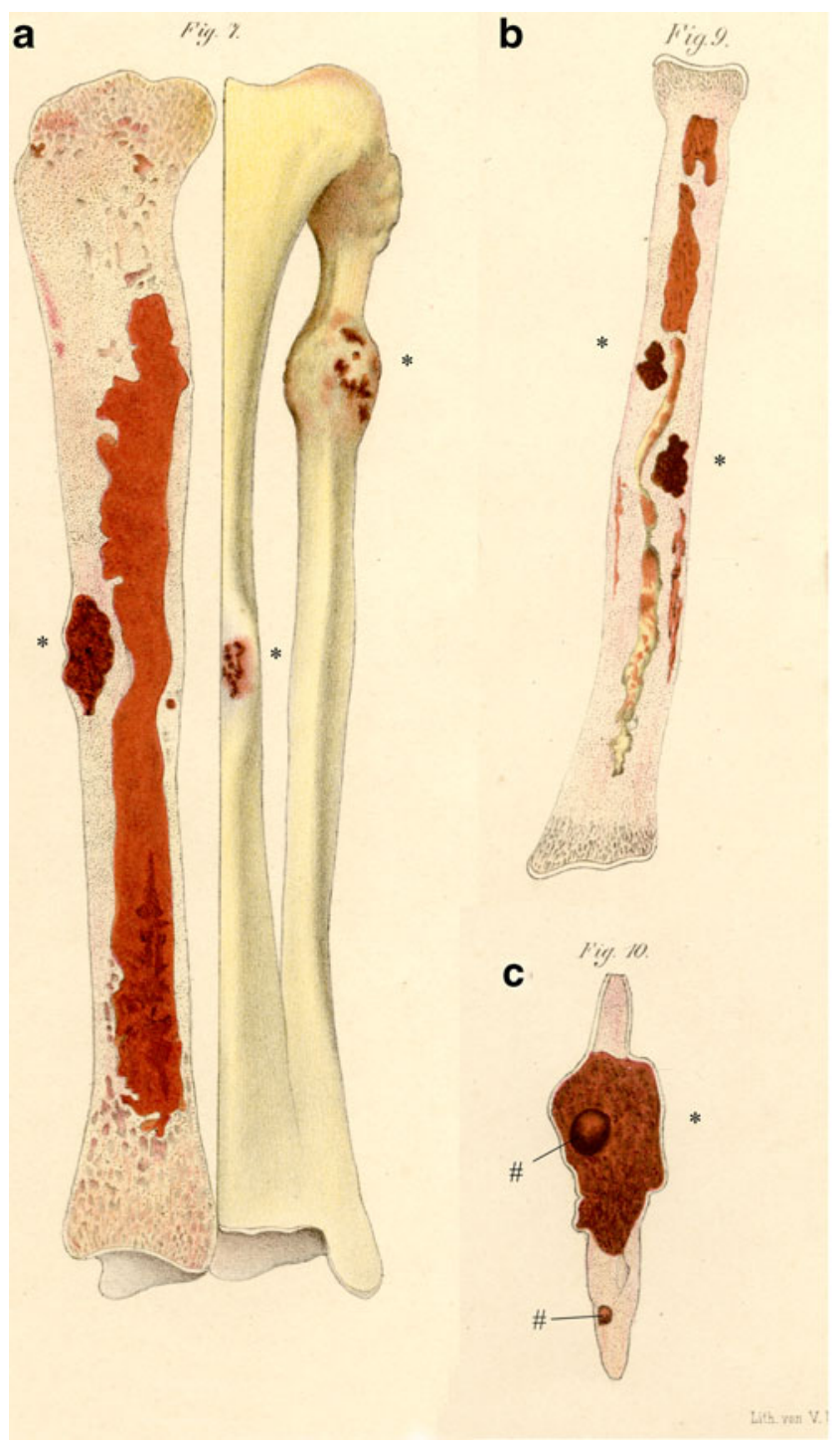

Fig. 6 a Left tibia and fibula, sagittal section through tibia; cortical new bone formation in the diaphysis with localization of brown tumor (asterisk). Expanding brown tumor (asterisk) in the proximal part of the fibula; $\mathbf{b}$ left radius, new bone formation in the diaphyseal cortex with two brown tumors (asterisk); c longitudinal section of a rib segment; expansive brown tumor (asterisk) with a smooth-walled cyst (number sign); intra-osseous cyst in porous section (number sign). Chromolithographic table [26]

graph he referred to the dissertation of Gerhard Engel from 1864 [28] where an almost identical case was presented; a finding recognized in the German literature where osteitis fibrosa is also known as an "Engel-Recklinghausen" disease.

\section{The relationship between osteitis fibrosa and tumor of the parathyreoids: the first evidence}

In his hand-written autopsy report of Mr. Bleich, Von Recklinghausen described a structure suggestive of an enlarged parathyroid gland, but nevertheless failed to establish a causal relationship between osteitis fibrosa and pathological changes in the parathyroids. Years later, in 1933, Adolphe Jung, a surgeon from Strasbourg reexamined two autopsy reports of osteitis fibrosa; both autopsies were carried out by von Recklinghausen, one case dated 1901 and the Bleich report that contained the remark: "Below the thyroid, on the left side, a lymph node, brownishred... normal thyroid volume, size of the thyroid ...". Possibly this " lymph node" was a parathyroid adenoma [29].

In 1904, Max Askanazy (1865-1940) from Bern published a classic case of osteitis fibrosa [30] in a 51year-old female patient who died from her illness. At autopsy Askanazy found goiter of the right thyroid lobe and a soft red-white tumor of $4.5 \times 2 \times 2 \mathrm{~cm}$ fixed to the left lobe. $\mathrm{He}$ considered the diagnosis of a tumor of a parathyroid gland. In discussing a possible cause of the skeletal abnormalities, Askanazy recommended paying special attention to the thyroid and other "vascular glands", without specifically referring to the fact that the patient had a parathyroid tumor.

\section{Breakthrough in the animal experiment: Jacob Erdheim}

Many surgeons continued to harbor the possibility, if not the firm belief, that thyroidectomy played a role in the occurrence of tetany and remained skeptical about the findings of Vassale and Generali. Moreover, many questioned the validity of applying conclusions drawn from animal experiments to human beings. All of this was to change around the turn of the century with the meticulous work of Jacob Erdheim (1874-1937), a pathologist from Vienna (Fig. 7). Erdheim developed a special interest in bone pathology and pathology of endocrine organs publishing several articles on these topics, in the course of which he made major contributions to clarifying the nature and role of the parathyroid glands [33].

In an ambitious animal experiment with rats Erdheim furnished convincing evidence that total parathyroidectomy leads to tetany. In the context of these animal studies he also examined three autopsy cases of patients who died of tetany after subtotal thyroidectomy. In none of these cases could there be found any remnant of functioning parathyroids. To achieve optimal results Erdheim proceeded with a remarkable degree of thoroughness assembling an astonishing number of histological slides; more than 10,000 sections of $30 \mu$ were prepared! In his animal experiment Erdheim made use of the rat because this animal has only two parathyroid glands, and these are easily accessible. Selective destruction of both glands and all their parts was 
carefully controlled and demonstrated by Erdheim, again by preparing serial histological sections of the neck organs.

A number of Erdheim's laboratory animals survived the attacks of tetany. Here again he displayed characteristic tenacity and indefatigability, continuing to follow these animals, as a result of which he made an additional surprising observation. On the 10th day after total parathyroidectomy, Erdheim observed developing abnormalities in enamel and dentin of the continuously growing incisors in a number of the rodents, their molars remained unchanged. In almost all surviving rats, three months after surgery, abnormal opacities were apparent in the tooth enamel and deficient calcium deposits in the dentin of the incisors could be histologically confirmed. The outcome of this disorder was severe, leading to deformity, fracture, and failure of the incisors (Fig. 8), followed by infection, ulceration, and abscess formation. The results of these experiments identify Erdheim as the first investigator to establish a role of the parathyroid glands in calcium metabolism. Erdheim presented his investigations, combined with many interesting historical, clinical, and pathological notes from the literature in the form of an impressive review article, entitled: "Tetania parathyreopriva" [15].

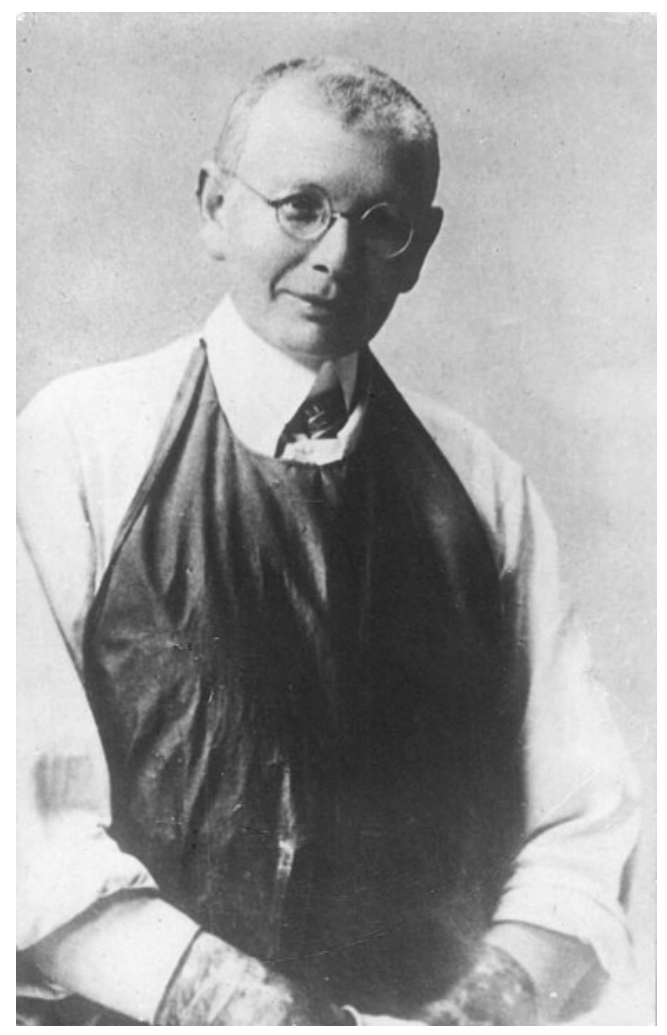

Fig. 7 Jacob Erdheim (1874-1934). After his education in the Department of pathology under professor Weichselbaum, Erdheim worked in a children's hospital for many years. Shortly after his appointment as pathologist in the Vienna Municipal Hospital, he was appointed as full professor of pathology. Courtesy Bildarchiv der Medizinischen Universität Wien

\section{Erdheim's theory}

Erdheim's experiments and his conclusions with respect to a role for the parathyroid glands in calcium metabolism caused general surprise and almost immediately raised questions concerning the function of the parathyroid glands in pathologic conditions such as osteomalacia, a disease that already was considered to be an "anomaly" in calcium metabolism.

Erdheim examined six autopsy cases of osteomalacia thoroughly. In four patients he found hyperplasia or microscopically observable foci of epithelial proliferation in one or more parathyroids; in one case a tumor of a single parathyroid gland was found [31].

In a subsequent experiment Erdheim demonstrated increased parathyroid volumes in rachitic rats [32]. Based on the sum of his observations, Erdheim came to consider the parathyroid glands as an important link in the pathogenesis of rickets and osteomalacia.

His hypothesis was stated as follows: "The parathyroid glands normally produce a fluid that enables osteoid to calcify. In cases of rickets and osteomalacia, this secretion is consumed or disintegrated in an unknown aberrant way, hampering osteoid to calcify which causes the characteristic changes of both disorders. The increased amount of osteoid induces stimulation of the parathyreoid glands resulting in hypertrophy or hyperplasia." [32].

\section{Doubts on Erdheim's theory in literature}

Erdheim's theory that increased parathyroid size is the result of, not the cause of, osteomalacia and rickets was generally accepted and further was also applied to osteitis fibrosa by several authors, who considered the latter disorder to be a variant of osteomalacia. Erdheim neither confirmed nor contested this view. Friedrich Schlagenhaufer (1866-1930), coincidentally also a pathologist from Vienna, was the first to question the applicability of Erdheim's theory to cases of osteitis fibrosa [34]. At a meeting of the "k.k. Gesellschaft der Ärzte in Wien" in 1915, Schlagenhaufer presented two cases of parathyroid tumor diagnosed at autopsy. Both patients suffered from osteomalacia, one of them with signs of osteitis fibrosa of the skull base. In the ensuing discussion Schlagenhaufer advocated removal of the parathyroid tumor in similar cases as a mode of therapy, an opinion supported by Maresch, one of his pathology colleagues. This interesting and practical suggestion gave rise to a rapidly expanding literature on the subject in the ensuing years. In one study of the literature, Siegfried Hoffheinz (1892-1953?) collected and described in 1925 seventeen autopsy cases of osteitis fibrosa [35]. In 12 cases, only one enlarged parathyroid gland was identified; in the 
Fig. 8 a Rat with normal incisors; $\mathbf{b}$ loss of both upper incisors and new growth. Enormous elongation of the lower incisors and pressure ulcer of the hard palate. Witte spot (asterisk) on the front side of both lower incisors. c Loss of both lower incisors. Ulcer of the mandible with visible new growth of lower incisors. Abnormal extension of both upper incisors and white spot (asterisk) on the front side of both incisors [15]. Courtesy of the library University of Nijmegen

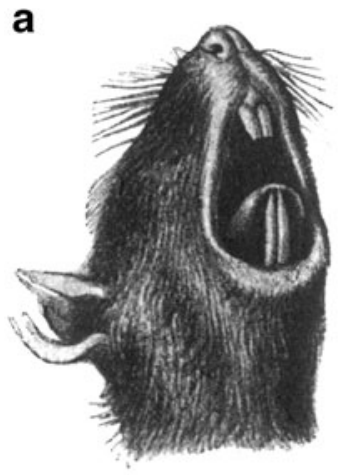

Fig. 25. Ratte mit normalen Nagezähnen.

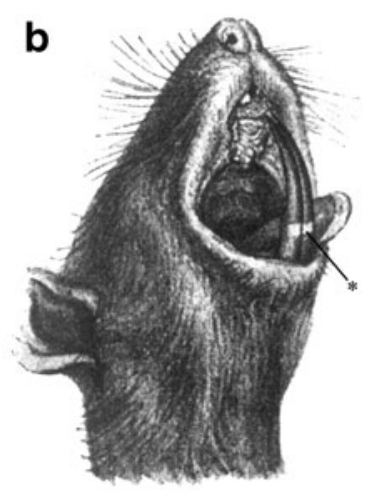

Fig. 26. Tetanieratte. Obere Nagezähne ausgefallen, beginnen eben nachzuwachsen. Untere Nagezähne enorm lang, erzeugen ein Druckgeschwür am harten Gaumen und weisen an der vorderen Fläche in gleicher Höhe einen weißen Fleck auf.

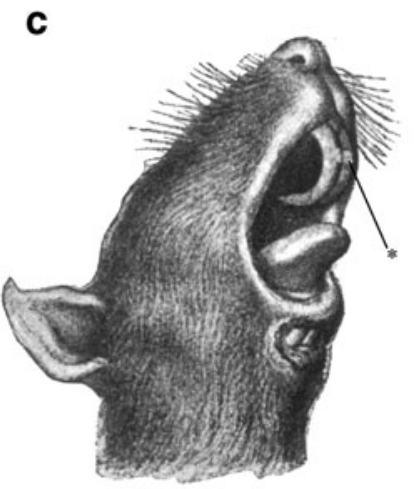

Fig. 27. Tetanieratte. Untere Nagez:̈hne ausgefallen. Am Unterkiefer ein Geschwür, in dem die Stümpfe der nachwachsenden unteren Nagezähne sichtbar sind. Die oberen Nagezähne abnorm lang, tra. gen in gleicher Höhe an der vorderen Fläche einen weißen Fleck. remaining cases two to four glands were enlarged. Whether the glands were hyperplastic or adenomatous was not established. Hoffheinz concluded somewhat tentatively, that Erdheim's "compensatory theory" probably did not apply to cases of osteitis fibrosa. One of the authors cited in the Hoffheinz paper even went so far as proposing the existence of a true parathyroid tumor in his autopsy case of osteitis fibrosa.

\section{Medical practice: Mandl's biological experiment by surgical intervention}

A practical proof that Erdheim's theory was not applicable in cases of osteitis fibrosa was provided by Felix Mandl (1892-1957), then resident of the university surgical clinics in Vienna [36]. In December 1925, Mandl examined and admitted to hospital a 38-year-old patient who suffered severe generalized osteitis fibrosa for 5 years. Major deformities were detected radiographically in both femora and in the pelvis; the skeleton was intensively decalcified and the excretion of calcium in urine was strongly increased. Initially, in concurrence with the generally held belief that Erdheim's theory applied to osteitis fibrosa, the patient was treated with tablets of 'parathyreoidin' (a parathyroid extract) and subsequently discharged. However, after a subsequent spontaneous fracture of the femur, the patient's general condition deteriorated, leading to readmission 4 months later. Again, consistent with Erdheim's compensatory theory, Mandl implanted four parathyroid glands from an accident victim, without any result. At this point, having achieved no clinical benefit, and having no further therapeutic options at his disposal Mandl began to question the validity of Erdheim's theory: was this theory really suitable in cases of osteitis fibrosa?
Influenced by Schlagenhaufer's proposal previously for removal of a parathyroid tumor in osteitis fibrosa, and perhaps encouraged by Hoffheinz's review of the literature offering tentative support, Mandl decided to intervene surgically, although clinical examination did not reveal enlarged glands in the neck area. However, during surgical exploration a definitive parathyroid tumor, measuring $25 \times$ $15 \times 12 \mathrm{~mm}$, was found and removed. The resected specimen was examined by Erdheim and Maresch and identified as parathyroid tissue; however, no precise diagnosis was made (hypertrophy or tumor) [36, 37]. Post-operatively the patient reported subjective improvements in symptoms, the pain disappeared and the patient was able to walk again using crutches. Furthermore, X-ray examination showed an increased density of the skeleton, and urine calcium excretion was significantly decreased.

This planned surgical intervention, which Mandl subsequently considered as a biological experiment, was a critical first step in proving a causal relationship between a parathyroid tumor and osteitis fibrosa; the parathyroid tumor was the cause, the osteitis fibrosa the result. This conclusion was, of course, directly opposed to Erdheim's compensatory theory. Mandl, perhaps in an exercise of diplomacy and respect, used the term "dysfunction" to indicate that in this special circumstance the enlarged parathyroid gland was the direct cause of the skeletal abnormalities. His conclusion that carried the benefit of offering a logical therapeutic response, namely resection of the tumor, in accordance with the inspired proposal by Schlagenhaufer was based on a single observation a decade earlier. This whole history of pathology and pathogenesis, complex and at times controversial, occurred in a period of 50 years, from the discovery of the existence of the parathyroid glands in man, to their linkage with osteitis fibrosa, and ultimately to successful surgical intervention 
for relief of the disease, a remarkably short time, as histories go, just two generations of physicians, surgeons, and pathologists.

Acknowledgments The author wishes to thank Erik Vermeulen for his critical remarks and Rob Reinders for his assistance in preparing the photographs. He is also grateful to Mr. Dreiss of Verlag Degener \& $\mathrm{CO}$ for providing figure 4 .

Conflict of Interest statement The author declares that he has no conflict of interest.

Open Access This article is distributed under the terms of the Creative Commons Attribution Noncommercial License which permits any noncommercial use, distribution, and reproduction in any medium, provided the original author(s) and source are credited.

\section{References}

1. Albright F (1948) A page out of the history of hyperparathyroidism. J Clin Endocrinol 8:637-657

2. Boothby W (1921) The parathyroid glands: a review of the literature. Endocrinology 5:403-440

3. Owen R (1862) On the anatomy of the Indian Rhinoceros (Rh. unicornus, L.). Trans Zool Soc Lond 4:31-58

4. Cave AJE (1975) Richard Owen and the discovery of the parathyroid glands. In: Underwood EA (ed) Science medicine and history, vol 2. Arno Press, New York, pp 217-222

5. Sandström I (1880) Om en ny körtel hos menniskan och atskilliga däggdjur. Ups Läkarefören Förh 15:441-471

6. Seipel CM (1938) On a new gland in man and several mammals (glandulae parathyreoideae) by Ivar Sandström. In: Peters $\mathrm{CH}$, Fulton JF (eds) On a new gland in man and several mammals (glandulae parathyreoideae). The Johns Hopkins Press, Baltimore, pp 14-44

7. Remak R (1855) Untersuchungen über die Entwickelung der Wirbelthiere. G. Reimer Berlin

8. Koelliker A (1879) Entwicklungsgeschichte des Menschen und der höheren Thiere. Verlag von Wilhelm Engelmann, Leipzig

9. Virchow R (1864-1865)Die krankhaften Geschwülste. Dreissig Vorlesungen gehalten während des Wintersemesters 1862-1863 an der Universität zu Berlin. Springer Verlag Berlin-Heidelberg-New York. 1978 ed. Vol. Band 3/I. Erste Hälfte. Verlag von August Hirschwald, Berlin p 13

10. Seipel CM (1938) Ivar Sandström $1852-1890$ by A.Hammar (English translation). In: Peters CH, Fulton JF (eds) On a new gland in man and several mammals (glandulae parathyreoideae). The Johns Hopkins Press, Baltimore, pp 3-13

11. Hæger K (1988) The illustrated history of surgery. Bell publishing company, New York, pp 241-243

12. Thorwald J (1957) Kocher oder Berner Tragödien. In: Das Weltreich der Chirurgen. Deutscher Bücherbund, StuttgartHamburg, pp 55-112

13. Morton LT, Normann JM (ed) (1991) Morton's medical Bibliography. 5th edn. Scolar Press, Aldershot, p 599

14. Weiss N (1881) Ueber Tetanie. Samml Klin Vortr Inn Med 63:1675-1704

15. Erdheim J (1906) Tetania parathyreopriva. Mitt a d Grenzgeb d Med u Chir 16:632-744
16. Berger W (1880) Ueber eine neue Drüse beim Menschen und bei verschiedenen Säugethieren; von Dr. Ivar Sandström. Schmidt's Jahrbücher der in-und ausländischen gesamten. Medicin 187:114 118

17. von Brunn W (1963) Medizinische Zeitschriften im neunzehnten Jahrhundert. Beiträge zur Geschichte der allgemein-medizinischen Fachpresse. Georg Thieme Verlag, Stuttgart

18. Gley ME (1891) Sur les fonctions du corps thyroïde. Compt rend hebd Soc de biol 43:841-847

19. Gley ME (1892) Effets de la Thyroidectomie chez le lapin. Arch de Physiol 4:135-147

20. Gley ME (1901) The Pathogeny of exophtalmic Goitre. BMJ 2256:771-773

21. Kohn A (1895) Studien über die Schilddrüse. Arch f mikr Anat 44:366-422

22. Kohn A (1896) Studien über die Schilddrüse II. Arch f mikr Anat 48:398-429

23. Vassale G, Generali F (1896) Sur les effets de l'extirpation des glandes parathyréoïdes. Arch Ital Biol 25:459-464

24. Vassale G, Generali F (1896) Sur les effets de l'extirpation des glandes parathyréoïdiennes. Arch Ital Biol 26:61-65

25. Festschrift Rudolf Virchow zu seinem 71. Geburtstage gewidmet von den früheren und jetziger Assistenten des Berliner pathologischen Instituts. (1891) G. Reimer, Berlin

26. Recklinghausen V F (1891) Die fibröse oder deformierende Ostitis, die Osteomalacie und die osteoplastische Carcinose in Ihren gegenseitigen Beziehungen. In: Festschrift R. Virchow zu seinem 71. Geburtstage. G. Reimer, Berlin

27. Recklinghausen v F (1910) Untersuchungen über Rachitis und Osteomalacie. Gustav Fischer, Jena

28. Engel G (1864) Ueber einen Fall von cystoider Entartung des gesammten Skelets. Inaugural-Dissertation. Thesis, Giessen

29. Jung AM (1933) Étude clinique de l'hyperparathyoïdisme. Cong fr Chir 42:199-268

30. Askanazy M (1904) Über Ostitis deformans ohne osteoides Gewebe. Arb a d Geb d path Anat Inst zu Tübingen 4:398422

31. Erdheim J (1907) Über Epithelkörperbefunde bei Osteomalacie. Sitzungsber d kais Akad d Wissensch in Wien, math naturw. Klasse Abt III 116:311-370

32. Erdheim J (1914) Rachitis und Epithelkörperchen. Alfred Hölder. In Kommission bei Alfred Hölder KuK. Hof-und Staatsdruckerei, Wien

33. Rabson AM (1959) Masters of modern Pathology: Jakob Erdheim. Arch Pathol 68:357-366

34. Schlagenhaufer F (1915) Zwei Fälle von Parathyreoideatumoren. Offizielles Protokoll der k.k. Gesellschaft der Aerzte in Wien Sitzung von 3 Dezember 1915. Wien Klin Wchenschr 28 (2): 1362

35. Hoffheinz S (1925) Über Vergrößerungen der Epithelkörperchen bei Ostitis fibrosa und verwandten Krankheitsbildern. Virch Arch f pathol Anat 256:705-735

36. Mandl F (1925) Therapeutischer Versuch bei Ostitis fibrosa generalisata mittels extirpation eines Epithelkörperchentumors. Wien Klin Wchenschr 38:1343-1344

37. Mandl F (1926) Klinisches und Experimentelles zur Frage der lokalisierten und generalisierten Ostitis fibrosa. Arch f klin Chir 143:245-284

38. Altmann HW (1982) Pathologie und Pathologen in Würzburg. In: Baumgart P (ed) Vierhundert Jahre Universität Würzburg. Verlag Degener \& Co, Inhaber Gerhard Gessner, Neustadt an der Aisch, pp 1011-1025 